\title{
Cellular responses and functions of $\alpha 7$ nicotinic acetylcholine receptor activation in the brain: a narrative review
}

\author{
Zhe-Qi Xu ${ }^{1,2}$, Wen-Jun Zhang ${ }^{3}$, Ding-Feng Su ${ }^{1}$, Guo-Qing Zhang ${ }^{2}$, Chao-Yu Miao ${ }^{1}$ \\ ${ }^{1}$ Department of Pharmacology, Second Military Medical University/Naval Medical University, Shanghai, China; ${ }^{2}$ Department of Pharmacy, Eastern \\ Hepatobiliary Surgery Hospital, Second Military Medical University/Naval Medical University, Shanghai, China; ${ }^{3}$ Department of Neurology, \\ Dongying People's Hospital, Dongying, China \\ Contributions: (I) Conception and design: CY Miao, GQ Zhang; (II) Administrative support: CY Miao, GQ Zhang; (III) Provision of study materials \\ or patients: None; (IV) Collection and assembly of data: None; (V) Data analysis and interpretation: None; (VI) Manuscript writing: All authors; (VII) \\ Final approval of manuscript: All authors. \\ Correspondence to: Chao-Yu Miao. Department of Pharmacology, Second Military Medical University/Naval Medical University, Shanghai 200433, \\ China. Email: cymiao@smmu.edu.cn; Guo-Qing Zhang. Department of Pharmacy, Eastern Hepatobiliary Surgery Hospital, Second Military Medical \\ University/Naval Medical University, Shanghai 200433, China. Email: gqzhang@smmu.edu.cn.
}

\begin{abstract}
The $\alpha 7$ nicotinic acetylcholine receptor ( $\alpha 7 \mathrm{nAChR})$ has been studied for many years since its discovery. Although many functions and characteristics of brain $\alpha 7 \mathrm{nAChR}$ are widely understood, much remains to be elucidated. The $\alpha 7 \mathrm{nAChR}$ is widely expressed in the central nervous system, not only in neurons but also in astrocytes, microglia, and endothelial cells. $\alpha 7 \mathrm{nAChR}$ can be activated by endogenous agonist like acetylcholine or exogenous agonists like nicotine and PNU282987. Its agonists can be divided into selective agonists and non-selective agonists. The activation of $\alpha 7 \mathrm{nAChR}$ results in a series of physiological processes which have both short-term and long-term effects on cells, for example, calcium influx, neurotransmitter release, synaptic plasticity, and excitatory transmission. It also induces other downstream events, such as inflammation, autophagy, necrosis, transcription, and apoptosis. The cellular responses to $\alpha 7 \mathrm{nAChR}$ activation vary according to cell types and conditions. For example, $\alpha 7 \mathrm{nAChR}$ activation in pyramidal neurons leads to long-term potentiation, while $\alpha 7 \mathrm{nAChR}$ activation in GABAergic interneurons leads to long-term depression. Studies have also shown some contradictory phenomena, which requires further study for clarification. Herein, the cellular responses of $\alpha 7 \mathrm{nAChR}$ activation are summarized, and the functions of $\alpha 7 \mathrm{nAChR}$ in neurons and non-neuronal cells are discussed. We also summarized contradictory conclusions to show where we stand and where to go for future studies.
\end{abstract}

Keywords: $\alpha 7$ nicotinic acetylcholine receptor $(\alpha 7 \mathrm{nAChR})$; signaling pathway; central nervous system diseases (CNS diseases); calcium influx; synaptic plasticity

Submitted Dec 10, 2020. Accepted for publication Feb 24, 2021.

doi: $10.21037 /$ atm-21-273

View this article at: http://dx.doi.org/10.21037/atm-21-273

\section{Introduction}

Nicotinic acetylcholine receptors (nAChRs) are cholinergic receptors which are activated by the endogenous neurotransmitter acetylcholine (1). Distinct from muscarinic acetylcholine receptors, nAChRs can also respond to nicotine, belonging to the cys-loop superfamily of receptors $(2,3)$. The $\mathrm{nAChR}$ is a pentameric ligandgated ion channel containing 5 homometric or heteromeric subunits (4). In total, 9 subunits have been found, and are named as $\alpha 2-7$ and $\beta 2-4(2,5,6)$. These 9 subunits can form different types of nAChRs, for example $(\alpha 4)_{3}(\beta 2)_{2} \mathrm{nAChR}$,

\footnotetext{
$\wedge$ ORCID: 0000-0002-6508-1038.
} 


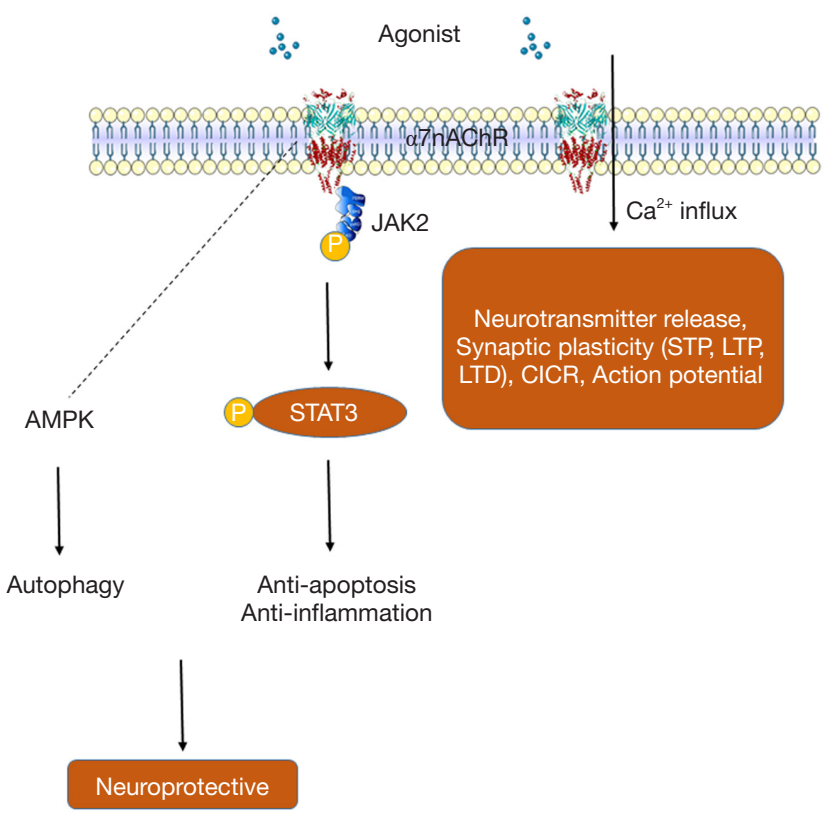

Figure 1 Cellular responses to $\alpha 7 \mathrm{nAChR}$ activation. The activation of $\alpha 7 \mathrm{nAChR}$ can lead to calcium influx directly, which can trigger neurotransmitter release, action potentials, synaptic plasticity, and calcium-induced calcium release. It can also activate the JAK2STAT3 signaling pathway and further induce anti-apoptotic and anti-inflammatory effects. In addition, it also activates the AMPKmTOR signaling pathway and induces autophagy. $\alpha 7 \mathrm{nAChR}, \alpha 7$ nicotinic acetylcholine receptor.

$(\alpha 4)_{2}(\beta 3)_{3} \mathrm{nAChR}$, and $(\alpha 3)_{2}(\beta 4)_{3} \mathrm{nAChR}$. The $\alpha 7$ nicotinic acetylcholine receptor $(\alpha 7 \mathrm{nAChR})$ is a special subtype of nAChR which consists of 5 homometric $\alpha 7$ subunits.

The $\alpha 7 \mathrm{nAChR}$ is widely expressed in the central nervous system (CNS), not only in neurons but also in astrocytes, microglia, and endothelial cells (7-9). It is one of the most well-studied ionotropic receptors. In neurons, it is believed that $\alpha 7 \mathrm{nAChR}$ plays an important role in synaptic plasticity, contributing to dependence, learning, memory, and other cognitive functions $(10,11)$. The activation of $\alpha 7 \mathrm{nAChR}$ can also contribute to neurotransmitter release, calcium influx, neuronal excitability, and other cellular activities (12-15). Studies have also revealed that the activation of $\alpha 7 \mathrm{nAChR}$ in microglia can induce anti-inflammatory effects $(16,17)$. As several benefits have been found, $\alpha 7 \mathrm{nAChR}$ is considered a promising therapeutic target in CNS diseases, such as psychiatric disorders including autism and schizophrenia, neurodegenerative diseases including Alzheimer's disease (AD) and Parkinson's disease (PD), and cerebrovascular diseases including hemorrhage stroke and ischemic stroke (18-21). Although, there were many reviews about $\alpha 7 \mathrm{nAChR}$ in the brain, many of them were focused on certain disease or were out of date. Some even reported contradictory conclusions. In this review, we will summarize recent researches on $\alpha 7 \mathrm{nAChR}$ in the brain and give an update snapshot of where we stand and where to head for in area of $\alpha 7 \mathrm{nAChR}$. This review will summarize the cellular responses to $\alpha 7 \mathrm{nAChR}$ activation and its different roles in various types of brain cells. We present the following article in accordance with the Narrative Review reporting checklist (available at http://dx.doi.org/10.21037/atm-21-273).

\section{Cellular responses to $\alpha 7 \mathrm{nAChR}$ activation}

As a ligand-gated ion channel, the activation of $\alpha 7 \mathrm{nAChR}$ can lead to a series of cellular responses, including but not limited to calcium influx, neurotransmitter release, synaptic plasticity, and excitatory transmission (12-15). It also induces other downstream events, such as inflammation, autophagy, necrosis, transcription, and apoptosis (Figure 1).

\section{$\alpha 7 n A C b R$ and calcium influx}

When the agonist binds to the ligand-binding domain of $\alpha 7 \mathrm{nAChR}$, the channel, which is composed of $5 \alpha 7$ subunits, opens to let cations through. The $\alpha 7 \mathrm{nAChR}$ has a high permeability to calcium (22). To determine this important physiological parameter, early studies used heterologous systems and reported permeability ratios of $\mathrm{P}_{\mathrm{Ca}} / \mathrm{P}_{\mathrm{Na}}$ as high as 15 to $20(3,23)$. However, Castro and Albuquerque used ion activities and the Goldman-Hodgkin-Katz equation for reversal potentials shifts to calculate the permeability ratios of $\mathrm{Ca}^{2+}$ in cultured rat hippocampal neurons. The results showed that the permeability ratio of $\mathrm{P}_{\mathrm{Ca}} / \mathrm{P}_{\mathrm{Na}}$ was $6.1 \pm 0.5$, which was much lower than the results determined by heterologous systems (24). The difference in permeability may be due to the different conditions. Another method to detect the $\mathrm{Ca}^{2+}$ permeability of $\alpha 7 \mathrm{nAChR}$ are fluorescent $\mathrm{Ca}^{2+}$ indicators $(25,26)$. This method records fluorescence signals and transmembrane currents simultaneously, and maintains good control of cell voltage and excludes any form of $\mathrm{Ca}^{2+}$-induced $\mathrm{Ca}^{2+}$ release (CICR) (25). The result is displayed as fractional calcium current $\left(\mathrm{P}_{\mathrm{f}}\right)$, indicating the percentage of the total current flowing through an ion channel which is carried by $\mathrm{Ca}^{2+}$. A study showed that the $\mathrm{P}_{\mathrm{f}}$ value of human neuronal $\alpha 7 \mathrm{nAChR}$ was $11.6 \%$, indicating $\alpha 7 \mathrm{nAChR}$ has a high calcium permeability (27). The 
activation of $\alpha 7 \mathrm{nAChR}$ not only raises cytoplasmic $\mathrm{Ca}^{2+}$ directly, but also indirectly. For example, the activation of $\alpha 7 \mathrm{nAChR}$ can depolarize neurons, and then induce calcium influx indirectly by voltage-dependent calcium channels

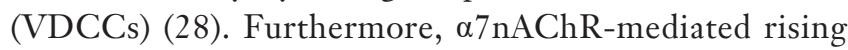
cytoplasmic calcium is partly caused by CICR from the endoplasmic reticulum (29). These are the 3 main ways that $\alpha 7 \mathrm{nAChR}$ can induce increased cytoplasmic $\mathrm{Ca}^{2+}$.

\section{a7nACbR and neurotransmitter release}

Neurotransmitter release usually occurs in the presynaptic membrane (30). The main processes of synaptic vesicle exocytosis and neurotransmitter release include: (I) the action potential arrives at the presynaptic terminals and depolarizes the terminal membrane; (II) the depolarized membrane induces calcium influx through VDCCs which dramatically increases the calcium concentration in the cytoplasm near the presynaptic membrane; (III) $\mathrm{Ca}^{2+}$ entry contributes to conformational changes in specific proteins in synaptic vesicles, leading to the fusion of synaptic vesicles to the presynaptic membrane. The whole process is an instantaneous response to the action potential, which lasts only a millisecond (31). Although neurotransmitter release is mainly triggered by VDCCs, in certain circumstances, $\alpha 7$ nAChR-mediated $\mathrm{Ca}^{2+}$ influx is sufficient to induce synaptic vesicles to release neurotransmitters. Gray et al. reported that nicotine acts on presynaptic $\alpha 7 \mathrm{nAChR}$ to enhance glutamatergic transmission in the hippocampus (13). It was also shown that activation of $\alpha 7 \mathrm{nAChR}$ in the presynaptic terminals of GABAergic neurons could increase GABA input to 5-HT dorsal raphe nucleus (DRN) neurons and lead to inhibitory postsynaptic spontaneous currents (32). This effect was triggered by $\alpha 7$ nAChR-mediated CICR in DRN GABAergic terminals.

However, neurotransmitter release is not only modulated by $\alpha 7 \mathrm{nAChR}$-mediated calcium changes, but is also regulated by $\alpha 7 \mathrm{nAChR}$-related signal transduction. Evidence has shown that the release of dopamine could be enhanced by the activation of $\alpha 7 \mathrm{nAChR}$, which was modulated through protein kinase C $(33,34)$.

\section{a7nACbR and synaptic plasticity}

Synaptic plasticity, such as short-term potentiation (STP), long-term potentiation (LTP), or long-term depression (LTD), is a neuronal property characterized by the ability of synapses to strengthen or weaken in response to their increased or decreased activity (35-37). Accumulating evidence suggests that it is one of the most important neurological foundations of learning and memory (38-40). Researchers found that in CA1 pyramidal neurons of the hippocampus, properly timed nicotine-mediated nAChR activation could contribute to the induction of LTP via presynaptic and postsynaptic pathways (41). The results showed that $\alpha 7 \mathrm{nAChR}$ contributed to most of these effects (41). However, different kinds of neurons had different outcomes. For GABAergic interneurons, the excitation caused inhibition of nearby pyramidal neurons, and the activation of $\alpha 7 \mathrm{nAChR}$-mediated synaptic plasticity led to LTD (41). This synaptic plasticity is associated with $\alpha 7 \mathrm{nAChR}$-mediated neurotransmitter release at the presynaptic membrane as well as $\alpha 7 \mathrm{nAChR}$-mediated postsynaptic depolarization and calcium signals (41). Nitta et al. reported that infusion of $\beta$-amyloid protein into cerebral ventricles for 14 days could lead to impairments in learning and cholinergic neuronal degeneration (42). Furthermore, Chen et al. reported a series of impairments in CA1 hippocampal slices, including basal synaptic transmission, LTP, post-tetanic potentiation (PTP), and paired-pulse facilitation (PPF) after continuous intracerebroventricular infusion of $\beta$-amyloid protein (43). They also found that activation of $\alpha 7 \mathrm{nAChR}$ was required for LTP induction, highlighting the association between $\alpha 7 \mathrm{nAChR}$ and synaptic plasticity (43). In addition to learning and memory, synaptic plasticity also participates in neuronal connections. Criscuolo et al. reported that they found impaired synaptic plasticity in the visual cortex of $\alpha 7 \mathrm{nAChR}$ knockout mice, indicating that $\alpha 7 \mathrm{nAChR}$ contributes to visual cortex function (44).

\section{$\alpha 7 n A C b R$ and anti-inflammatory effects}

The relationship between the nervous system and the immune system has been studied for several decades, and it has been consistently demonstrated that these 2 systems interact with each other. Researchers found that stimulation of the vagus nerve could attenuate inflammation by inhibiting macrophage tumor-necrosis factor (TNF) release (45). Further results suggested that this phenomenon was mediated by $\alpha 7 \mathrm{nAChR}$ responding to acetylcholine $(45-47)$. Hence, the anti-inflammatory effect of the vagal nerve is termed the "cholinergic anti-inflammatory pathway (CAP)" $(45,46)$.

The $\alpha 7 \mathrm{nAChR}$ is widely expressed in cells of the immune system, such as macrophages, monocytes, and lymphocytes 
(48-50). Pinheiro et al. reported that treatment with PNU282987, an $\alpha 7 \mathrm{nAChR}$ agonist, could reduce LPSinduced acute lung injury through reducing neutrophil recruitment and IL- $1 \beta$, TNF- $\alpha$, and IL- 6 levels via changing the macrophage profile (51). Our lab also found that combination treatment with anisodamine (antagonist of muscarinic acetylcholine receptors) and neostigmine (cholinesterase inhibitor), which promoted the binding of endogenous acetylcholine to $\alpha 7 \mathrm{nAChR}$, could rescue crush syndrome by reducing inflammation, and this phenomenon was absent in $\alpha 7 \mathrm{nAChR}$ knockout mice (52). Several studies have revealed that the attenuation of inflammatory cytokine release from macrophages by activating $\alpha 7 \mathrm{nAChR}$ was through the JAK2/STAT3 signaling pathway (16,52-54).

In addition to the roles of $\alpha 7 \mathrm{nAChR}$ in the peripheral CAP, many studies have investigated whether such roles exist in the CNS. In the brain, microglia are the resident immune cells, and the activation of these cells accounts for neuroinflammation $(55,56)$. Shytle et al. reported for the first time that the brain CAP regulated microglial activation through $\alpha 7 \mathrm{nAChR}$, and pretreatment with nicotine could reduce LPS-induced TNF- $\alpha$ release (47). Furthermore, De Simone et al. also demonstrated the existence of the CAP in the brain and the expression of $\alpha 7 \mathrm{nAChR}$ in microglia, and found that nicotine enhanced the expression of cyclooxygenase- 2 and the synthesis of one of its major products, prostaglandin E2 (12). Our lab also demonstrated in vivo that activation of microglial $\alpha 7 \mathrm{nAChR}$ by PNU282987 reduced the production of IL-6, IL-1 $\beta$, IL-18, and TNF- $\alpha$, thereby alleviating experimental autoimmune encephalomyelitis $(57,58)$.

\section{a7nACbR and autophagy}

Autophagy or "self-eating" is, as its name suggests, a basic cellular process that degrades and recycles misfolded or long-lived proteins and damaged organelles (59). Evidence has shown that autophagy is involved in the pathophysiological changes in many CNS diseases (60-65). Hung et al. found that $\alpha 7 \mathrm{nAChR}$ could bind with amyloid $\beta(\mathrm{A} \beta)$ and internalize into the cytoplasm to further inhibit $A \beta$-induced neurotoxicity through autophagy (66). They further demonstrated in vivo and in vitro that overexpression of LC3 led to neuroprotective effects by increasing $\alpha 7 \mathrm{nAChR}$ expression, which increased binding to $A \beta$ and enhanced autophagy activity (67). Jeong et al. also found that $\alpha 7 \mathrm{nAChR}$ could be modulated and upregulated by melatonin, which enhanced autophagy and exerted neuroprotective effects on prion diseases (68). Our lab has focused on $\alpha 7 \mathrm{nAChR}$ for many years and found that activation of $\alpha 7 \mathrm{nAChR}$ by PNU282987 enhanced microglia autophagy and suppressed neuroinflammation in experimental autoimmune encephalomyelitis mice (57). Enhanced autophagy induced by $\alpha 7 \mathrm{nAChR}$ activation was mediated by AMPK-mTOR-P70S6K signaling pathway activation (57). Interestingly, Hou et al. reported that autophagy was inhibited by $\alpha 7 \mathrm{nAChR}$ activation using PNU282987 and induced protection against myocardial ischemia/reperfusion injury in vivo and hypoxia/ reoxygenation injury in primary cardiomyocytes in vitro (69). They demonstrated that these effects were mediated by JAK2 and PI3K activation in cardiomyocytes (69). These different phenomena in microglia and cardiomyocytes indicate that the relationship between autophagy and $\alpha 7 \mathrm{nAChR}$ activation varies in different organs or cells (70).

\section{a7nACbR and anti-apoptotic effects}

It has been demonstrated that activation of $\alpha 7 \mathrm{nAChR}$ can affect cellular apoptosis (71-73). De Rosa et al. reported that nicotine upregulated $\alpha 7 \mathrm{nAChR}$ in human lymphocytes, which then decreased cortisol-induced apoptosis (71). However, the authors did not address the underlying mechanisms of this finding. Furthermore, Hejmadi et al. found that the presence of nicotine could protect primary cortical neurons against apoptosis induced by oxygen deprivation, which was mediated by 2 subtypes of nAChR, including $\alpha 7 \mathrm{nAChR}$ and $\beta 2 \mathrm{nAChR}$ (74). Further studies have revealed the mechanisms of nicotine-mediated antiapoptotic effects. Toborek et al. reported that the antiapoptotic effect of $\alpha 7 \mathrm{nAChR}$ activation in spinal cord neurons was dependent on increased phosphorylated ERK1/2 and total ERK1/2 activity, indicating that the ERK1/2 signaling pathway was involved in the antiapoptotic effects of nicotine (75). It is interesting that different signaling pathways involved in $\alpha 7 \mathrm{nAChR}$-mediated anti-apoptotic effects have been found by researchers. Parada et al. found that PNU282987 could rescue rotenone and oligomycin A-induced apoptosis via the JAK2/PI3K/ Akt cascade in SH-SY5Y cells (72). In addition, Marrero and Bencherif reported that nicotine induced anti-apoptotic effects targeting $\alpha 7 \mathrm{nAChR}$ mainly through JAK2 activation, increased NF- $\kappa \mathrm{B}$, and the production of $\mathrm{Bcl}-2$ in PC12 cells (73). It is interesting that different signaling pathways have been found to be involved in the same phenomenon. This may be due to the different cells and different stimuli 
used in studies.

\section{Functions of $\alpha 7 \mathrm{nAChR}$ in neurons and non- neuronal cells}

\section{a7nACbR in neurons}

The $\alpha 7 \mathrm{nAChR}$ is widely expressed in neurons. It is also found in different locations in neurons, including the presynaptic membrane, postsynaptic membrane, and perisynaptic sites $(76,77)$. The activation of $\alpha 7 \mathrm{nAChR}$ in neurons mainly leads to calcium-dependent events and a variety of other downstream signaling events which depend on receptor location. In general, activation of $\alpha 7 \mathrm{nAChR}$ leads to calcium influx which increases $\mathrm{Ca}^{2+}$ levels in neurons, triggering downstream responses $(13,78,79)$. The basic neuronal physiological functions cannot be achieved without $\alpha 7 \mathrm{nAChR}$. Activation of $\alpha 7 \mathrm{nAChR}$ in the presynaptic membrane leads to transmitter release, which contributes to synaptic transmission. Also, the effect of transmitter release induced by $\alpha 7 \mathrm{nAChR}$ does not need other forms of calcium influx like VDCCs or CICR (13). Postsynaptic $\alpha 7 \mathrm{nAChR}$ activation participates in intracellular signaling cascades and downstream processes. The most important function is to influence synaptic plasticity related to learning, memory, and addiction (80-82). As discussed above, properly-timed activation of $\alpha 7 \mathrm{nAChR}$ produces LTP or LTD, which remodels and strengthens connections within neuronal networks.

Furthermore, many studies have reported that $\alpha 7 \mathrm{nAChR}$ activation can have anti-apoptotic effects on neurons (83-85). A series of signaling pathways involved in the anti-apoptotic effects mediated by $\alpha 7 \mathrm{nAChR}$ have been uncovered. Huang et al. reported that neuroprotection by nicotine against colchicine-induced neuronal apoptosis was mediated by the PI3K/Akt signaling pathway (85). Also, Yu et al. demonstrated that $\alpha 7 \mathrm{nAChR}$ activation reduced $\beta$-amyloid-induced neuronal apoptosis through the PI3K signaling pathway (86). However, Chen et al. reported that the $\alpha 7 \mathrm{nAChR}$ agonist PHA568487 inhibited neuronal apoptosis through the TLR/Myd88/NF- $\mathrm{B}$ signaling pathway (83).

Moreover, as mentioned above, Hung et al. reported that $\alpha 7 \mathrm{nAChR}$ could induce $\mathrm{A} \beta$ transport into the cytoplasm and promote degradation through autophagy in SH-SY5Y cells (66). Jeong and Park also indicated that $\alpha 7 \mathrm{nAChR}$ upregulated autophagy in SH-SY5Y cells and protected against prion-mediated mitochondrial neurotoxicity (68).
In summary, $\alpha 7 \mathrm{nAChR}$ activation not only contributes to instantaneous processes such as calcium influx and neurotransmitter release, which comprise basic neuronal functions, it also participates in long-term effects like synaptic plasticity, and influences intracellular signaling pathways to produce anti-apoptotic effects and increased autophagy.

\section{$\alpha 7 n A C b R$ in astrocytes}

Astrocytes are star-shaped glial cells in the CNS. According to the research, astrocytes in the brain account for $20 \%$ to $40 \%$ of all glial cells. For a long time, scientists regarded astrocytes as merely support cells for neurons. However, many important functions have been recently uncovered, including but not limited to the regulation of neurotransmitters, the maintenance of the blood-brain barrier (BBB), the formation of the tripartite synapse, metabolic support, glucose sensing, the regulation of ion concentration in the extracellular space, and the repair of CNS injury through glial scar formation (87-95).

The $\alpha 7 \mathrm{nAChR}$ is also distributed in astrocytes and its activation can influence cellular functions (96). Teaktong et al. reported that the expression of $\alpha 7 \mathrm{nAChR}$ in astrocytes was increased in $\mathrm{AD}$ compared to that in dementia with Lewy bodies, which might contribute to alterations in calcium homeostasis and nitric oxide production in response to $A \beta$-mediated inflammation in $\mathrm{AD}(97)$. Yu et al. also found a significant increase of $\alpha 7 \mathrm{nAChR}$ expression in astrocytes in patients with $\mathrm{AD}$ or in patients carrying the Swedish APP 670/671 mutation, however, it was more pronounced in patients carrying the Swedish APP 670/671 mutation (98). They further indicated that the increased expression of $\alpha 7 \mathrm{nAChR}$ in astrocytes was positively correlated with the extent of pathological changes, especially the number of neuritic plaques in $\mathrm{AD}$ patients, which indicates its important role in the pathogenesis of AD (98). Although these studies demonstrated the relationship between $\alpha 7 \mathrm{nAChR}$ in astrocytes and CNS diseases, they did not describe the exact roles of $\alpha 7 \mathrm{nAChR}$ in these diseases. Later, Liu et al. reported the protective effect of $\alpha 7 \mathrm{nAChR}$ against dopaminergic neuron loss in a PD model via inhibition of astrocyte activation (99). In contrast to this finding, Talantova et al. reported that $\mathrm{A} \beta$ induced astrocytic glutamate release through $\alpha 7 \mathrm{nAChR}$, which activated extrasynaptic NMDA receptors on neurons and damaged synapses in AD (100). Taken together, $\alpha 7 \mathrm{nAChR}$ activation in astrocytes can lead to different 
effects under different conditions, which may be dependent on various ligands or brain regions.

\section{a7nACbR in microglia}

Microglia are the brain's resident immune cells, which contribute to CNS inflammation. Decades ago, Wang et al. demonstrated that $\alpha 7 \mathrm{nAChR}$ was essential for acetylcholine inhibition of macrophage TNF- $\alpha$ release, which was named CAP (45). Whether its counterpart microglia also had this effect was a mystery until Shytle and colleagues uncovered it in their study (47). For the first time, Shytle et al. indicated that $\alpha 7 \mathrm{nAChR}$ was expressed in primary cultured microglial cells and brain slices (47). In addition, pretreatment with acetylcholine and nicotine inhibited LPS-induced TNF- $\alpha$ release in microglial cells, and this effect could be attenuated by $\alpha$-bungarotoxin, a $\alpha 7 \mathrm{nAChR}$ antagonist (47). Many other studies have also demonstrated this effect (101-107). However, Thomsen et al. found that blockade of $\alpha 7 \mathrm{nAChR}$ by the antagonists methyllycaconitine (MLA) and NS6740 reduced LPS-induced microglia TNF- $\alpha$ release, which indicated that the $\alpha 7 \mathrm{nAChR}$-induced antiinflammatory effects of microglia were not due to calcium influx through ion channels (108).

Furthermore, Suzuki et al. also reported that the nicotine-induced increase in microglia intracellular $\mathrm{Ca}^{2+}$ levels was independent of extracellular $\mathrm{Ca}^{2+}$, and this effect could be blocked by the phospholipase C (PLC) inhibitor U73122 and the inositol trisphosphate $\left(\mathrm{IP}_{3}\right)$ receptor blocker xestospongin $\mathrm{C}$ (101). In addition, nicotine-modulated LPS-mediated TNF- $\alpha$ release was also blocked by U73122 and xestospongin $\mathrm{C}$ (101). They suggested that nicotine triggered intracellular $\mathrm{Ca}^{2+}$ increases in microglia and their anti-inflammatory effects, which were mediated through the activation of PLC and $\mathrm{Ca}^{2+}$ release from the endoplasmic reticulum (101). Other signaling pathways involved in $\alpha 7 \mathrm{nAChR}$-mediated microglial anti-inflammatory effects have also been uncovered. Parada et al. discovered a new signaling pathway involved in $\alpha 7 \mathrm{nAChR}$-mediated neuronal protection in ischemic stroke (104). They suggested that activation of $\alpha 7 \mathrm{nAChR}$ in microglia contributed to the CAP through nuclear factor erythroid-2-related factor 2 (Nrf2) and heme oxygenase-1 (HO-1) activation, leading to neuroprotective effects in ischemic stroke (104). Morioka et al. also suggested a novel mechanism of microglial $\alpha 7 \mathrm{nAChR}$-mediated neuroprotection beyond antiinflammatory effects (109). They reported that treatment of microglia with nicotine significantly increased the expression of the glutamate/aspartate transporter (GLAST), which is the main transporter in microglia, and increased glutamate uptake (109). The upregulation of GLAST was mainly through the $\mathrm{IP}_{3}$ and $\mathrm{Ca}^{2+}$ /calmodulin-dependent protein kinase II (CaMKII) signaling pathway (109).

\section{$\alpha 7 n A C b R$ in cerebrovascular endothelial cells}

It was first reported in 2001 by Wang et al. that $\alpha 7 \mathrm{nAChR}$ was expressed in human bronchial epithelial and endothelial cells (110). They used both western blot and immunohistochemistry with an anti- $\alpha 7 \mathrm{nAChR}$ antibody and demonstrated that $\alpha 7 \mathrm{nAChR}$ was expressed in human aortic endothelial cells (110). They also used patch-clamp and found that the presence of fast desensitization currents activated by acetylcholine and nicotine could be blocked by MLA and $\alpha$-bungarotoxin, thus further demonstrating the presence of $\alpha 7 \mathrm{nAChR}$ in endothelial cells (110). In spite of this discovery, they still did not know the exact role of $\alpha 7 \mathrm{nAChR}$. In 2006, $\mathrm{Li}$ and Wang reported that the $\alpha 7 \mathrm{nAChR}$ agonist choline increased $\alpha 7 \mathrm{nAChR}$ expression, proliferation, and tube formation in human umbilical vein endothelial cells (HUVECs), and this phenomenon could be reversed by applying the antagonist $\alpha$-bungarotoxin in vitro (111). They also investigated capillary density in a myocardial infarction (MI) rat model and reported that an $\alpha 7 \mathrm{nAChR}$ agonist increased capillary density in infarct tissues while the antagonists reversed this effect (111). This study indicated that activation of $\alpha 7 \mathrm{nAChR}$ could contribute to angiogenesis.

$\mathrm{Ng}$ et al. investigated the relationship between $\alpha 7 \mathrm{nAChR}$ and angiogenesis (112). They found that nicotine could dose-dependently enhance human microvascular endothelial cell (HMVEC) migration, which is a key process in angiogenesis (112). Furthermore, the induction of angiogenesis by other growth factors, including fibroblast growth factor (FGF) and vascular endothelial growth factor (VEGF), also relied on the activation of $\alpha 7 \mathrm{nAChR}$, as their effect was abolished or attenuated after treatment with the $\alpha 7 \mathrm{nAChR}$ antagonist $\alpha$-bungarotoxin (112). Wu et al. also detected the mRNA expression of $\alpha 7 \mathrm{nAChR}$ by RT-PCR in a series of human endothelial cell types: human pulmonary arterial endothelial cells (HPAEC), HMVECs, HUVECs, and human retinal endothelial cells (HREC) (113). Consistent with previous studies, they found that $\alpha 7 \mathrm{nAChR}$ was expressed in these cell types, however, there were differences in the levels of expression (113). Higher 
Table 1 Studies show contradictory findings

\begin{tabular}{|c|c|c|c|c|}
\hline $\begin{array}{l}\text { Related } \\
\text { functions }\end{array}$ & Author/year & Cell type/region & Primary findings & Species \\
\hline \multirow{2}{*}{$\begin{array}{l}\alpha 7 n A C h R \\
\text { and synaptic } \\
\text { plasticity }\end{array}$} & Ji D et al. (2001) & $\begin{array}{l}\text { GABAergic } \\
\text { interneuron }\end{array}$ & \multirow{2}{*}{$\begin{array}{l}\text { Activation of } \alpha 7 \mathrm{nAChR} \text { by Ach can mediate synaptic } \\
\text { plasticity leads to LTD, which can be blocked by } \\
\text { methyllycaconitine (MLA) } \\
\text { Activation of } \alpha 7 \mathrm{nAChR} \text { by [3-(2,4-dimethoxybenzylidene)- } \\
\text { anabaseine] (DMXB) can induce LTP which can be blocked } \\
\text { by MLA or alpha-bungarotoxin (alpha-BTX) }\end{array}$} & Mouse \\
\hline & Chen L et al. (2006) & $\begin{array}{l}\text { Brain hippocampal } \\
\text { slice }\end{array}$ & & Rat \\
\hline \multirow{2}{*}{$\begin{array}{l}\alpha 7 \mathrm{nAChR} \text { and } \\
\text { autophagy }\end{array}$} & Hou Z et al. (2018) & Cardiomyocyte & \multirow{2}{*}{$\begin{array}{l}\text { Activation of } \alpha 7 \mathrm{nAChR} \text { by PNU282987 inhibits Beclin-1 } \\
\text { associated autophagy and reduces cardiomyocyte injury } \\
\text { induced by hypoxia/reoxygenation } \\
\text { Activation of } \alpha 7 \mathrm{nAChR} \text { by PNU282987 enhanced microglia } \\
\text { autophagy and suppressed neuroinflammation }\end{array}$} & Rat \\
\hline & Shao BZ et al. (2017) & Microglia & & Mouse \\
\hline \multirow[t]{2}{*}{$\begin{array}{l}\alpha 7 \mathrm{nAChR} \text { in } \\
\text { astrocytes }\end{array}$} & Liu Y et al. (2012) & $\begin{array}{c}\text { Astrocyte and } \\
\text { dopaminergic neuron }\end{array}$ & \multirow{2}{*}{$\begin{array}{l}\text { Activation of } \alpha 7 \mathrm{nAChR} \text { has protective effect against } \\
\text { dopaminergic neuron loss in PD model via inhibition of } \\
\text { astrocyte activation } \\
\text { Amyloid- } \beta \text { binds to } \alpha 7 \mathrm{nAChR} \text { to induce release of astrocytic } \\
\text { glutamate, which activates NMDA receptors and damages } \\
\text { synapse in AD }\end{array}$} & Mouse \\
\hline & $\begin{array}{c}\text { Talantova } \\
\text { M et al. (2013) }\end{array}$ & Astrocyte and neuron & & $\begin{array}{l}\text { Rat, mouse, } \\
\text { and human }\end{array}$ \\
\hline \multirow{2}{*}{$\begin{array}{l}\alpha 7 \mathrm{nAChR} \text { in } \\
\text { cerebrovascular } \\
\text { endothelial cells }\end{array}$} & $\begin{array}{c}\text { Abbruscato } \\
\text { TJ et al. (2002) }\end{array}$ & $\begin{array}{l}\text { Brain microvessel } \\
\text { endothelial cells }\end{array}$ & \multirow{2}{*}{$\begin{array}{l}\text { Nicotine and cotinine can increase permeability of blood- } \\
\text { brain barrier under hypoxia condition and reduce expression } \\
\text { of ZO-1, which canbu reversed by } \alpha 7 n A C h R \text { antagonist } \\
\text { PHA543613 can decrease permeability of blood-brain } \\
\text { barrier and increase expression of claudin- } 5 \text { by activating } \\
\alpha 7 n A C h R\end{array}$} & Bovine \\
\hline & Kimura I et al. (2018) & Brain endothelial cells & & Rat \\
\hline
\end{tabular}

$\alpha 7 \mathrm{nAChR}, \alpha 7$ nicotinic acetylcholine receptor; LTD, long-term depression; LTP, long-term potentiation; AD, Alzheimer's disease.

a7nAChR expression was detected in HUVECs (113). They also reported that $\alpha 7 \mathrm{nAChR}$ plays a dominant role in nicotine-induced cell signaling and endothelial cell migration, proliferation, and tube formation (113).

In spite of the positive effects of $\alpha 7 \mathrm{nAChR}$ activation in these endothelial cells, studies in cerebrovascular endothelial cells showed contrasting results. Abbruscato and colleagues reported in 2002 that nicotine and its metabolite, cotinine, could increase the permeability of the $\mathrm{BBB}$ in a bovine brain microvessel endothelial cell model under hypoxic condition (114). Furthermore, nicotine and cotinine reduced the expression of ZO-1 (tight junction protein) which could be reversed by the $\alpha 7 \mathrm{nAChR}$ antagonist $\alpha$-bungarotoxin, indicating that both the nicotine and cotinine-induced effects were mediated by the $\alpha 7 \mathrm{nAChR}$ (114). However, Kimura et al. reported different results in 2018. They demonstrated that the selective $\alpha 7$ nAChR agonist PHA543613 decreased the permeability of the BBB and increased the expression of claudin- 5 and occludin, which are key tight junction components (115). Additionally, they did not show a positive effect of nicotine. The different results may be due to the different agonists and different in vitro models used in studies.

\section{Conclusions}

Based on the discussion above, evidence from in vivo and in vitro studies has shown significant cellular responses to $\alpha 7 \mathrm{nAChR}$ activation. However, some results are contradictory and require further study (Table 1). For example, although $\alpha 7 \mathrm{nAChR}$ is a ligand-gated ion channel, it can also increase intracellular cAMP levels through adenylate cyclase 1 (AC1), which is a common signaling pathway of G protein coupled receptors (116). Does 
$\alpha 7$ nAChR activate AC1 directly or indirectly? The cellular responses and functions of $\alpha 7 \mathrm{nAChR}$ in the brain show promising therapeutic effects in CNS diseases. The many benefits of $\alpha 7 \mathrm{nAChR}$ activation in the CNS may be the reason why smokers are at a lower risk of developing $\mathrm{PD}$ compared with non-smokers (117). As $\alpha 7 \mathrm{nAChR}$ has various effects on cells, agonists, antagonists, and other allosteric modulators are widely used in many animal models to study CNS diseases. Many agonists or allosteric modulators are involved in clinical trials to treat CNS diseases. However, whether these $\alpha 7 \mathrm{nAChR}$ targeting drugs have adverse effects or not should be studied in-depth.

\section{Acknowledgments}

Funding: None.

\section{Footnote}

Reporting Checklist: The authors have completed the Narrative Review reporting checklist. Available at http:// dx.doi.org/10.21037/atm-21-273

Conflicts of Interest: All authors have completed the ICMJE uniform disclosure form (available at http://dx.doi. org/10.21037/atm-21-273). The authors have no conflicts of interest to declare.

Ethical Statement: The authors are accountable for all aspects of the work in ensuring that questions related to the accuracy or integrity of any part of the work are appropriately investigated and resolved.

Open Access Statement: This is an Open Access article distributed in accordance with the Creative Commons Attribution-NonCommercial-NoDerivs 4.0 International License (CC BY-NC-ND 4.0), which permits the noncommercial replication and distribution of the article with the strict proviso that no changes or edits are made and the original work is properly cited (including links to both the formal publication through the relevant DOI and the license). See: https://creativecommons.org/licenses/by-nc-nd/4.0/.

\section{References}

1. Gay EA, Yakel JL. Gating of nicotinic ACh receptors; new insights into structural transitions triggered by agonist binding that induce channel opening. J Physiol
2007;584:727-33.

2. Dani JA, Bertrand D. Nicotinic acetylcholine receptors and nicotinic cholinergic mechanisms of the central nervous system. Annu Rev Pharmacol Toxicol 2007;47:699-729.

3. Seguela P, Wadiche J, Dineley-Miller K, et al. Molecular cloning, functional properties, and distribution of rat brain alpha 7: a nicotinic cation channel highly permeable to calcium. J Neurosci 1993;13:596-604.

4. Brejc K, van Dijk WJ, Klaassen RV, et al. Crystal structure of an ACh-binding protein reveals the ligand-binding domain of nicotinic receptors. Nature 2001;411:269-76.

5. Yakel JL. Cholinergic receptors: functional role of nicotinic ACh receptors in brain circuits and disease. Pflugers Arch 2013;465:441-50.

6. Hurst R, Rollema H, Bertrand D. Nicotinic acetylcholine receptors: from basic science to therapeutics. Pharmacol Ther 2013;137:22-54.

7. Quik M, Polonskaya Y, Gillespie A, et al. Localization of nicotinic receptor subunit mRNAs in monkey brain by in situ hybridization. J Comp Neurol 2000;425:58-69.

8. Palma E, Conti L, Roseti C, et al. Novel approaches to study the involvement of alpha7-nAChR in human diseases. Curr Drug Targets 2012;13:579-86.

9. Dineley KT, Pandya AA, Yakel JL. Nicotinic ACh receptors as therapeutic targets in CNS disorders. Trends Pharmacol Sci 2015;36:96-108.

10. Nordman JC, Phillips WS, Kodama N, et al. Axon targeting of the alpha 7 nicotinic receptor in developing hippocampal neurons by Gprin1 regulates growth. J Neurochem 2014;129:649-62.

11. Zhao X, Kuryatov A, Lindstrom JM, et al. Nootropic drug modulation of neuronal nicotinic acetylcholine receptors in rat cortical neurons. Mol Pharmacol 2001;59:674-83.

12. De Simone R, Ajmone-Cat MA, Carnevale D, et al. Activation of alpha7 nicotinic acetylcholine receptor by nicotine selectively up-regulates cyclooxygenase- 2 and prostaglandin $\mathrm{E} 2$ in rat microglial cultures. J Neuroinflammation 2005;2:4.

13. Gray R, Rajan AS, Radcliffe KA, et al. Hippocampal synaptic transmission enhanced by low concentrations of nicotine. Nature 1996;383:713-6.

14. Fucile S, Palma E, Mileo AM, et al. Human neuronal threonine-for-leucine-248 alpha 7 mutant nicotinic acetylcholine receptors are highly $\mathrm{Ca} 2+$ permeable. Proc Natl Acad Sci U S A 2000;97:3643-8.

15. Chamberlin NL, Bocchiaro CM, Greene RW, et al. Nicotinic excitation of rat hypoglossal motoneurons. Neuroscience 2002;115:861-70. 
16. Shi S, Liang D, Bao M, et al. Gx-50 Inhibits Neuroinflammation via alpha7 $\mathrm{nAChR}$ Activation of the JAK2/STAT3 and PI3K/AKT Pathways. J Alzheimers Dis 2016;50:859-71.

17. Frasch MG, Szynkaruk M, Prout AP, et al. Decreased neuroinflammation correlates to higher vagus nerve activity fluctuations in near-term ovine fetuses: a case for the afferent cholinergic anti-inflammatory pathway? J Neuroinflammation 2016;13:103.

18. Olincy A, Blakeley-Smith A, Johnson L, et al. Brief Report: Initial Trial of Alpha7-Nicotinic Receptor Stimulation in Two Adult Patients with Autism Spectrum Disorder. J Autism Dev Disord 2016;46:3812-7.

19. Haig G, Wang D, Othman AA, et al. The alpha7 Nicotinic Agonist ABT-126 in the Treatment of Cognitive Impairment Associated with Schizophrenia in Nonsmokers: Results from a Randomized Controlled Phase 2b Study. Neuropsychopharmacology 2016;41:2893-902.

20. Echeverria V, Yarkov A, Aliev G. Positive modulators of the alpha7 nicotinic receptor against neuroinflammation and cognitive impairment in Alzheimer's disease. Prog Neurobiol 2016;144:142-57.

21. Kawamata J, Suzuki S, Shimohama S. alpha7 nicotinic acetylcholine receptor mediated neuroprotection in Parkinson's disease. Curr Drug Targets 2012;13:623-30.

22. Barrantes GE, Westwick J, Wonnacott S. Nicotinic acetylcholine receptors in primary cultures of hippocampal neurons: pharmacology and $\mathrm{Ca}++$ permeability. Biochem Soc Trans 1994;22:294S.

23. Bertrand D, Galzi JL, Devillers-Thiery A, et al. Mutations at two distinct sites within the channel domain M2 alter calcium permeability of neuronal alpha 7 nicotinic receptor. Proc Natl Acad Sci U S A 1993;90:6971-5.

24. Castro NG, Albuquerque EX. alpha-Bungarotoxinsensitive hippocampal nicotinic receptor channel has a high calcium permeability. Biophys J 1995;68:516-24.

25. Grynkiewicz G, Poenie M, Tsien RY. A new generation of $\mathrm{Ca} 2+$ indicators with greatly improved fluorescence properties. J Biol Chem 1985;260:3440-50.

26. Neher $\mathrm{E}$. The use of fura-2 for estimating $\mathrm{Ca}$ buffers and Ca fluxes. Neuropharmacology 1995;34:1423-42.

27. Fucile S, Renzi M, Lax P, et al. Fractional Ca(2+) current through human neuronal alpha7 nicotinic acetylcholine receptors. Cell Calcium 2003;34:205-9.

28. Rathouz MM, Berg DK. Synaptic-type acetylcholine receptors raise intracellular calcium levels in neurons by two mechanisms. J Neurosci 1994;14:6935-45.

29. Gueorguiev VD, Zeman RJ, Meyer EM, et al.
Involvement of alpha7 nicotinic acetylcholine receptors in activation of tyrosine hydroxylase and dopamine beta-hydroxylase gene expression in PC12 cells. J Neurochem 2000;75:1997-2005.

30. Kavalali ET. The mechanisms and functions of spontaneous neurotransmitter release. Nat Rev Neurosci 2015;16:5-16.

31. Sudhof TC. Neurotransmitter release: the last millisecond in the life of a synaptic vesicle. Neuron 2013;80:675-90.

32. Hernandez-Vazquez F, Chavarria K, Garduno J, et al. Nicotine increases GABAergic input on rat dorsal raphe serotonergic neurons through alpha7 nicotinic acetylcholine receptor. J Neurophysiol 2014;112:3154-63.

33. Quarta D, Naylor CG, Barik J, et al. Drug discrimination and neurochemical studies in alpha7 null mutant mice: tests for the role of nicotinic alpha7 receptors in dopamine release. Psychopharmacology (Berl) 2009;203:399-410.

34. Soliakov L, Wonnacott S. Involvement of protein kinase C in the presynaptic nicotinic modulation of $[(3) \mathrm{H}]$-dopamine release from rat striatal synaptosomes. Br J Pharmacol 2001;132:785-91.

35. Hughes JR. Post-tetanic potentiation. Physiol Rev 1958;38:91-113.

36. Bocchio M, Nabavi S, Capogna M. Synaptic Plasticity, Engrams, and Network Oscillations in Amygdala Circuits for Storage and Retrieval of Emotional Memories. Neuron 2017;94:731-43.

37. Basu J, Siegelbaum SA. The Corticohippocampal Circuit, Synaptic Plasticity, and Memory. Cold Spring Harb Perspect Biol 2015;7:a021733.

38. Martin SJ, Grimwood PD, Morris RG. Synaptic plasticity and memory: an evaluation of the hypothesis. Annu Rev Neurosci 2000;23:649-711.

39. Pignatelli M, Umanah GKE, Ribeiro SP, et al. Synaptic Plasticity onto Dopamine Neurons Shapes Fear Learning. Neuron 2017;93:425-40.

40. Mills F, Globa AK, Liu S, et al. Cadherins mediate cocaine-induced synaptic plasticity and behavioral conditioning. Nat Neurosci 2017;20:540-9.

41. Ji D, Lape R, Dani JA. Timing and location of nicotinic activity enhances or depresses hippocampal synaptic plasticity. Neuron 2001;31:131-41.

42. Nitta A, Itoh A, Hasegawa T, et al. beta-Amyloid proteininduced Alzheimer's disease animal model. Neurosci Lett 1994;170:63-6.

43. Chen L, Yamada K, Nabeshima T, et al. alpha7 Nicotinic acetylcholine receptor as a target to rescue deficit in hippocampal LTP induction in beta-amyloid infused rats. 
Neuropharmacology 2006;50:254-68.

44. Criscuolo C, Accorroni A, Domenici L, et al. Impaired synaptic plasticity in the visual cortex of mice lacking alpha7-nicotinic receptor subunit. Neuroscience 2015;294:166-71.

45. Wang H, Yu M, Ochani M, et al. Nicotinic acetylcholine receptor alpha7 subunit is an essential regulator of inflammation. Nature 2003;421:384-8.

46. Wang H, Liao H, Ochani M, et al. Cholinergic agonists inhibit HMGB1 release and improve survival in experimental sepsis. Nat Med 2004;10:1216-21.

47. Shytle RD, Mori T, Townsend K, et al. Cholinergic modulation of microglial activation by alpha 7 nicotinic receptors. J Neurochem 2004;89:337-43.

48. Zabrodskii PF, Maslyakov VV, Gromov MS. Role of alpha7-Nicotinic Acetylcholine Receptors of B Cells in the Immunotoxic Effect of Organophosphorus Compounds. Bull Exp Biol Med 2016;161:779-81.

49. Zanetti SR, Ziblat A, Torres NI, et al. Expression and Functional Role of alpha7 Nicotinic Receptor in Human Cytokine-stimulated Natural Killer (NK) Cells. J Biol Chem 2016;291:16541-52.

50. Liu Z, Han B, Li P, et al. Activation of alpha7nAChR by nicotine reduced the Th17 response in CD4(+)T lymphocytes. Immunol Invest 2014;43:667-74.

51. Pinheiro NM, Santana FP, Almeida RR, et al. Acute lung injury is reduced by the alpha7nAChR agonist PNU282987 through changes in the macrophage profile. FASEB J 2017;31:320-32.

52. Xu ZQ, Shao BZ, Ke P, et al. Combined administration of anisodamine and neostigmine rescued acute lethal crush syndrome through alpha7nAChR-dependent JAK2STAT3 signaling. Sci Rep 2016;6:37709.

53. Lu XX, Hong ZQ, Tan Z, et al. Nicotinic Acetylcholine Receptor Alpha7 Subunit Mediates Vagus Nerve Stimulation-Induced Neuroprotection in Acute Permanent Cerebral Ischemia by a7nAchR/JAK2 Pathway. Med Sci Monit 2017;23:6072-81.

54. Yang YH, Li DL, Bi XY, et al. Acetylcholine Inhibits LPSInduced MMP-9 Production and Cell Migration via the alpha7 nAChR-JAK2/STAT3 Pathway in RAW264.7 Cells. Cell Physiol Biochem 2015;36:2025-38.

55. Giulian D. Ameboid microglia as effectors of inflammation in the central nervous system. J Neurosci Res 1987;18:155-71,32-3.

56. Lassmann H, Zimprich F, Rossler K, et al. Inflammation in the nervous system. Basic mechanisms and immunological concepts. Rev Neurol (Paris) 1991;147:763-81.
57. Shao BZ, Ke P, Xu ZQ, et al. Autophagy Plays an Important Role in Anti-inflammatory Mechanisms Stimulated by Alpha7 Nicotinic Acetylcholine Receptor. Front Immunol 2017;8:553.

58. Ke $\mathrm{P}$, Shao $\mathrm{BZ}, \mathrm{Xu} Z \mathrm{ZQ}$, et al. Activating alpha7 nicotinic acetylcholine receptor inhibits NLRP3 inflammasome through regulation of beta-arrestin-1. CNS Neurosci Ther 2017;23:875-84.

59. Moulis M, Vindis C. Autophagy in Metabolic Age-Related Human Diseases. Cells 2018;7:149.

60. Sun Y, Zhang T, Zhang Y, et al. Ischemic Postconditioning Alleviates Cerebral Ischemia-Reperfusion Injury Through Activating Autophagy During Early Reperfusion in Rats. Neurochem Res 2018;43:1826-40.

61. Xu L, Zhang C, Jiang N, et al. Rapamycin combined with MCC950 to treat multiple sclerosis in experimental autoimmune encephalomyelitis. J Cell Biochem 2019;120:5160-8.

62. Morandi E, Jagessar SA, t Hart BA, et al. EBV Infection Empowers Human B Cells for Autoimmunity: Role of Autophagy and Relevance to Multiple Sclerosis. J Immunol 2017;199:435-48.

63. Aminyavari S, Zahmatkesh M, Farahmandfar M, et al. Protective role of Apelin-13 on amyloid beta25-35induced memory deficit; Involvement of autophagy and apoptosis process. Prog Neuropsychopharmacol Biol Psychiatry 2019;89:322-34.

64. Hung COY, Livesey FJ. Altered gamma-Secretase Processing of APP Disrupts Lysosome and Autophagosome Function in Monogenic Alzheimer's Disease. Cell Rep 2018;25:3647-60.e2.

65. Varmazyar R, Noori-Zadeh A, Rajaei F, et al. 17 betaEstradiol Oxidative Stress Attenuation and AutophagyInduced Dopaminergic Neuroprotection. Cell J 2019;21:1-6.

66. Hung SY, Huang WP, Liou HC, et al. Autophagy protects neuron from Abeta-induced cytotoxicity. Autophagy 2009;5:502-10.

67. Hung SY, Huang WP, Liou HC, et al. LC3 overexpression reduces Abeta neurotoxicity through increasing alpha7nAchR expression and autophagic activity in neurons and mice. Neuropharmacology 2015;93:243-51.

68. Jeong JK, Park SY. Melatonin regulates the autophagic flux via activation of alpha-7 nicotinic acetylcholine receptors. J Pineal Res 2015;59:24-37.

69. Hou Z, Zhou Y, Yang H, et al. Alpha7 nicotinic acetylcholine receptor activation protects against myocardial reperfusion injury through modulation 
of autophagy. Biochem Biophys Res Commun 2018;500:357-64.

70. Klionsky DJ, Abdelmohsen K, Abe A, et al. Guidelines for the use and interpretation of assays for monitoring autophagy (3rd edition). Autophagy 2016;12:1-222.

71. De Rosa MJ, Esandi Mdel C, Garelli A, et al. Relationship between alpha $7 \mathrm{nAChR}$ and apoptosis in human lymphocytes. J Neuroimmunol 2005;160:154-61.

72. Parada E, Egea J, Romero A, et al. Poststress treatment with PNU282987 can rescue SH-SY5Y cells undergoing apoptosis via alpha7 nicotinic receptors linked to a Jak2/ Akt/HO-1 signaling pathway. Free Radic Biol Med 2010;49:1815-21.

73. Marrero MB, Bencherif $M$. Convergence of alpha 7 nicotinic acetylcholine receptor-activated pathways for anti-apoptosis and anti-inflammation: central role for JAK2 activation of STAT3 and NF-kappaB. Brain Res 2009;1256:1-7.

74. Hejmadi MV, Dajas-Bailador F, Barns SM, et al. Neuroprotection by nicotine against hypoxia-induced apoptosis in cortical cultures involves activation of multiple nicotinic acetylcholine receptor subtypes. Mol Cell Neurosci 2003;24:779-86.

75. Toborek M, Son KW, Pudelko A, et al. ERK 1/2 signaling pathway is involved in nicotine-mediated neuroprotection in spinal cord neurons. J Cell Biochem 2007;100:279-92.

76. Jones IW, Wonnacott S. Precise localization of alpha7 nicotinic acetylcholine receptors on glutamatergic axon terminals in the rat ventral tegmental area. J Neurosci 2004;24:11244-52.

77. Marshall LM. Synaptic localization of alpha-bungarotoxin binding which blocks nicotinic transmission at frog sympathetic neurons. Proc Natl Acad Sci U S A 1981;78:1948-52.

78. Shoop RD, Chang KT, Ellisman MH, et al. Synaptically driven calcium transients via nicotinic receptors on somatic spines. J Neurosci 2001;21:771-81.

79. Vogt KE, Regehr WG. Cholinergic modulation of excitatory synaptic transmission in the CA3 area of the hippocampus. J Neurosci 2001;21:75-83.

80. Sultan A, Yang KS, Isaev D, et al. Thujone inhibits the function of alpha7-nicotinic acetylcholine receptors and impairs nicotine-induced memory enhancement in one-trial passive avoidance paradigm. Toxicology 2017;384:23-32.

81. Li J, Bo L, Zhang P, et al. Exposure to nicotine during pregnancy and altered learning and memory in the rat offspring. Nicotine Tob Res 2015;17:661-6.
82. Wei XM, Yang W, Liu LX, et al. Effects of L-arginine and N(omega)-nitro-L-arginine methylester on learning and memory and alpha7 nAChR expression in the prefrontal cortex and hippocampus of rats. Neurosci Bull 2013;29:303-10.

83. Chen K, Sun Y, Diao Y, et al. alpha7 nicotinic acetylcholine receptor agonist inhibits the damage of rat hippocampal neurons by TLR4/Myd88/NFkappaB signaling pathway during cardiopulmonary bypass. $\mathrm{Mol}$ Med Rep 2017;16:4770-6.

84. Sun Y, Song D, Wang M, et al. alpha7 nicotinic acetylcholine receptor agonist attenuates the cerebral injury in a rat model of cardiopulmonary bypass by activating the Akt/GSK3beta pathway. Mol Med Rep 2017;16:7979-86.

85. Huang X, Cheng Z, Su Q, et al. Neuroprotection by nicotine against colchicine-induced apoptosis is mediated by PI3-kinase--Akt pathways. Int J Neurosci 2012;122:324-32.

86. Yu W, Mechawar N, Krantic S, et al. alpha7 Nicotinic receptor activation reduces beta-amyloid-induced apoptosis by inhibiting caspase-independent death through phosphatidylinositol 3-kinase signaling. J Neurochem 2011;119:848-58.

87. Araque A, Parpura V, Sanzgiri RP, et al. Tripartite synapses: glia, the unacknowledged partner. Trends Neurosci 1999;22:208-15.

88. Abbott NJ, Ronnback L, Hansson E. Astrocyte-endothelial interactions at the blood-brain barrier. Nat Rev Neurosci 2006; 7:41-53.

89. McDougal DH, Viard E, Hermann GE, et al. Astrocytes in the hindbrain detect glucoprivation and regulate gastric motility. Auton Neurosci 2013;175:61-9.

90. Figley CR, Stroman PW. The role(s) of astrocytes and astrocyte activity in neurometabolism, neurovascular coupling, and the production of functional neuroimaging signals. Eur J Neurosci 2011;33:577-88.

91. Santello M, Volterra A. Synaptic modulation by astrocytes via $\mathrm{Ca} 2+-$ dependent glutamate release. Neuroscience 2009;158:253-9.

92. Walz W. Role of astrocytes in the clearance of excess extracellular potassium. Neurochem Int 2000;36:291-300.

93. Piet R, Vargova L, Sykova E, et al. Physiological contribution of the astrocytic environment of neurons to intersynaptic crosstalk. Proc Natl Acad Sci U S A 2004;101:2151-5.

94. Anderson MA, Burda JE, Ren Y, et al. Astrocyte scar formation aids central nervous system axon regeneration. 
Nature 2016;532:195-200.

95. Patti L, Raiteri L, Grilli M, et al. Evidence that alpha7 nicotinic receptor modulates glutamate release from mouse neocortical gliosomes. Neurochem Int 2007;51:1-7.

96. Grybko M, Sharma G, Vijayaraghavan S. Functional distribution of nicotinic receptors in CA3 region of the hippocampus. J Mol Neurosci 2010;40:114-20.

97. Teaktong T, Graham A, Court J, et al. Alzheimer's disease is associated with a selective increase in alpha7 nicotinic acetylcholine receptor immunoreactivity in astrocytes. Glia 2003;41:207-11.

98. Yu WF, Guan ZZ, Bogdanovic N, et al. High selective expression of alpha7 nicotinic receptors on astrocytes in the brains of patients with sporadic Alzheimer's disease and patients carrying Swedish APP 670/671 mutation: a possible association with neuritic plaques. Exp Neurol 2005;192:215-25.

99. Liu Y, Hu J, Wu J, et al. alpha7 nicotinic acetylcholine receptor-mediated neuroprotection against dopaminergic neuron loss in an MPTP mouse model via inhibition of astrocyte activation. J Neuroinflammation 2012;9:98.

100. Talantova M, Sanz-Blasco S, Zhang X, et al. Abeta induces astrocytic glutamate release, extrasynaptic NMDA receptor activation, and synaptic loss. Proc Natl Acad Sci U S A 2013;110:E2518-27.

101.Suzuki T, Hide I, Matsubara A, et al. Microglial alpha7 nicotinic acetylcholine receptors drive a phospholipase C/IP3 pathway and modulate the cell activation toward a neuroprotective role. J Neurosci Res 2006;83:1461-70.

102. Ohnishi M, Katsuki H, Takagi M, et al. Long-term treatment with nicotine suppresses neurotoxicity of, and microglial activation by, thrombin in cortico-striatal slice cultures. Eur J Pharmacol 2009;602:288-93.

103. Mencel M, Nash M, Jacobson C. Neuregulin upregulates microglial alpha7 nicotinic acetylcholine receptor expression in immortalized cell lines: implications for regulating neuroinflammation. PLoS One 2013;8:e70338.

104. Parada E, Egea J, Buendia I, et al. The microglial alpha7acetylcholine nicotinic receptor is a key element in promoting neuroprotection by inducing heme oxygenase-1 via nuclear factor erythroid-2-related factor 2. Antioxid Redox Signal 2013;19:1135-48.

105.Hua S, Ek CJ, Mallard C, et al. Perinatal hypoxiaischemia reduces alpha 7 nicotinic receptor expression and selective alpha 7 nicotinic receptor stimulation suppresses inflammation and promotes microglial Mox phenotype. Biomed Res Int 2014;2014:718769.

106.Jiang Y, Li L, Liu B, et al. Vagus nerve stimulation attenuates cerebral ischemia and reperfusion injury via endogenous cholinergic pathway in rat. PLoS One 2014;9:e102342.

107.Lutz JA, Kulshrestha M, Rogers DT, et al. A nicotinic receptor-mediated anti-inflammatory effect of the flavonoid rhamnetin in BV2 microglia. Fitoterapia 2014;98:11-21.

108. Thomsen MS, Mikkelsen JD. The alpha7 nicotinic acetylcholine receptor ligands methyllycaconitine, NS6740 and GTS-21 reduce lipopolysaccharide-induced TNF-alpha release from microglia. J Neuroimmunol 2012;251:65-72.

109. Morioka N, Tokuhara M, Nakamura Y, et al. Primary cultures of rat cortical microglia treated with nicotine increases in the expression of excitatory amino acid transporter 1 (GLAST) via the activation of the alpha7 nicotinic acetylcholine receptor. Neuroscience 2014;258:374-84.

110. Wang Y, Pereira EF, Maus AD, et al. Human bronchial epithelial and endothelial cells express alpha7 nicotinic acetylcholine receptors. Mol Pharmacol 2001;60:1201-9.

111.Li XW, Wang H. Non-neuronal nicotinic alpha 7 receptor, a new endothelial target for revascularization. Life Sci 2006;78:1863-70.

112. Ng MK, Wu J, Chang E, et al. A central role for nicotinic cholinergic regulation of growth factor-induced endothelial cell migration. Arterioscler Thromb Vasc Biol 2007;27:106-12.

113. Wu JC, Chruscinski A, De Jesus Perez VA, et al. Cholinergic modulation of angiogenesis: role of the 7 nicotinic acetylcholine receptor. J Cell Biochem 2009;108:433-46.

114.Abbruscato TJ, Lopez SP, Mark KS, et al. Nicotine and cotinine modulate cerebral microvascular permeability and protein expression of ZO-1 through nicotinic acetylcholine receptors expressed on brain endothelial cells. J Pharm Sci 2002;91:2525-38.

115. Kimura I, Dohgu S, Takata F, et al. Activation of the alpha7 nicotinic acetylcholine receptor upregulates bloodbrain barrier function through increased claudin- 5 and 
occludin expression in rat brain endothelial cells. Neurosci Lett 2019;694:9-13.

116. Cheng Q, Yakel JL. Activation of alpha7 nicotinic acetylcholine receptors increases intracellular cAMP levels via activation of $\mathrm{AC} 1$ in hippocampal neurons.

Cite this article as: Xu ZQ, Zhang WJ, Su DF, Zhang GQ, Miao CY. Cellular responses and functions of $\alpha 7$ nicotinic acetylcholine receptor activation in the brain. Ann Transl Med 2021;9(6):509. doi: 10.21037/atm-21-273
Neuropharmacology 2015;95:405-14.

117. Gallo V, Vineis P, Cancellieri M, et al. Exploring causality of the association between smoking and Parkinson's disease. Int J Epidemiol 2019;48:912-25. 